\title{
PENERAPAN MODEL PEMBELAJARAN KOOPERATIF TIPE NUMBERED HEADS TOGETHER (NHT) UNTUK MENINGKATKAN HASIL BELAJAR SISWA KELAS IV SDN 1 LELEWAWO
}

\author{
Ajid $^{1)}$, Yoo Eka Yana Kansil ${ }^{2}$ \\ ${ }^{1)}$ SDN 1 Lelewawo, Kolaka Utara, Indonesia \\ ${ }^{2)}$ Jurusan PGSD, Universitas Halu Oleo, Kendari, Indonesia \\ email:ajidlelewawo172@gmail.com
}

\begin{abstract}
Abstrak: Jenis penelitian ini adalah penelitian tindakan kelas. Penelitian ini dilaksanakan pada semester I Tahun Ajaran 2016/2017 bertempat di kelas IV SD Negeri 1 Lelewawo. Prosedur penelitian ini meliputi: perencanaan, pelaksanaan tindakan, observasi, evaluasi dan refleksi. Hasil analisis data dapat dijelaskan satupersatu berikut ini: Hasil observasi skenario pembelajaran aktivitas mengajar guru siklus I pertemuan 1 sebesar $63,63 \%$ dan pertemuan 2 sebesar $72,72 \%$, hasil observasi aktivitas belajar siswa siklus I pertemuan I sebesar $55,55 \%$ dan pertemuan 2 sebesar $66,66 \%$. Hasil tes siklus I diperoleh sebesar $60 \%$ Tuntas dan $40 \%$ tidak tuntas. Kemudian hasil observasi skenario pembelajaran aktivitas mengajar guru siklus II pertemuan 1 sebesar $81,81 \%$ dan pertemuan 2 sebesar 90,90\%, hasil observasi aktivitas belajar siswa siklus II pertemuan 1 sebesar $77,77 \%$ dan pertemuan 2 sebesar $88,88 \%$. Hasil tes siklus II diperoleh sebesar $90 \%$ Tuntas dan $10 \%$ tidak tuntas. Dengan demikian dapat ditarik kesimpulan bahwa hasil belajar siswa pada materi pokok keliling dan luas bangun datar melalui penerapan model pembelajaran kooperatif tipe NHT dapat ditingkatkan khususnya di SD Negeri 1 Lelewawo Tahun pelajaran 2016/2017.
\end{abstract}

Kata Kunci: Pembelajaran Kooperatif; Numbered Head Together; Hasil Belajar.

\section{APPLICATION OF NUMBERED HEADS TOGETHER (NHT) COOPERATIVE LEARNING MODELS TO IMPROVE STUDENT LEARNING OUTCOMES IN CLASSES IV OF SDN 1 LELEWAWO}

\begin{abstract}
This type of research is classroom action research. This research was conducted in the first semester of the 2016/2017 academic year at the fourth grade of SD Negeri 1 Lelewawo. This research procedure includes: planning, implementing actions, observation, evaluation and reflection. The results of data analysis can be explained one by one as follows: The results of the observation of the learning scenario of the teaching activities of the teacher in the first cycle of meeting 1 were $63.63 \%$ and the second meeting was $72.72 \%$, the results of the observation of student learning activities in the first cycle of meeting I were $55.55 \%$ and meeting 2 amounted to $66.66 \%$. The results of the first cycle test were $60 \%$ complete and $40 \%$ incomplete. Then the results of the observation of the scenario of teaching learning activities of the teacher in the second cycle of meeting 1 amounted to $81.81 \%$ and meeting 2 was $90.90 \%$, the results of the observation of student learning activities in the second cycle of meeting 1 were $77.77 \%$ and meeting 2 was $88.88 \%$. The results of the second cycle test were $90 \%$ complete and $10 \%$ incomplete. Thus it can be concluded that student learning outcomes on the subject matter of the circumference and area of a flat shape through the application of the NHT type cooperative learning model can be improved, especially in SD Negeri 1 Lelewawo in the 2016/2017 academic year.
\end{abstract}

Keywords: Cooperative Learning; Numbered Head Together; Learning outcomes. 


\section{Pendahuluan}

Pendidikan merupakan media yang sangat berperan untuk menciptakan manusia yang berkualitas dan berpotensi dalam arti yang seluas-luasnya, melalui pendidikan akan terjadi proses pendewasaan diri sehingga di dalam proses pengambilan keputusan terhadap suatu masalah yang dihadapi selalu disertai dengan rasa tanggung jawab yang besar

Mengingat peran pendidikan tersebut maka sudah seyogyanya aspek ini menjadi perhatian pemerintah dalam rangka meningkatkan sumber daya masyarakat Indonesia yang berkualitas. Matematika sebagai salah satu mata pelajaran di sekolah dinilai cukup memegang peranan penting dalam membentuk siswa menjadi berkualitas. Karena itu, maka perlu adanya peningkatan mutu pelajaran matematika. Salah satu hal yang harus diperhatikan adalah peningkatan hasil belajar matematika siswa di sekolah. Dalam pembelajaran di sekolah, matematika merupakan salah satu mata pelajaran yang kurang dipahami oleh sebagian siswa, kemudian pada umumnya guru masih menerapkan metode mengajar konvensional seperti metode ceramah. Oleh karena itu dalam proses pembelajaran matematika diperlukan suatu metode mengajar yang bervariasi. Bervariasi artinya jangan hanya metode tetapi juga harus menerapkan model pembelajaran kooperatif berbagai tipe yang telah dilakukan oleh berbagai ahli pembelajaran. Pada SD Negeri 1 Lelewawo terjadi kondisi dimana penguasaan siswa terhadap materi matematika masih tergolong rendah. Berdasarkan pengalaman penulis sebagai guru yang mengajar di kelas IV bahwa penguasaan materi matematika oleh siswa masih tergolong rendah.

Salah satu materi matematika yang penguasaan siswa rendah adalah pada materi keliling dan luas bangun datar. Hal ini dapat dilihat dari hasil ulangan harian siswa pada materi keliling dan luas bangun datar semester I tahun 2015/2016 dari 30 orang siswa hanya $50 \%$ atau 15 orang siswa yang memperoleh nilai minimal 65. Rendahnya hasil belajar matematika siswa dipengaruhi oleh berbagai faktor, diantaranya adalah model pembelajaran yang oleh guru. Guru masih menggunakan model konvensional yakni suatu model pembelajaran yang banyak didominasi oleh guru, sementara siswa duduk secara pasif menerima informasi pengetahuan dan keterampilan. Hal ini diduga merupakan salah satu penyebab terhambatnya kreativitas dan kemandirian siswa.

Melihat fenomena tersebut, maka perlu diterapkan suatu sistem pembelajaran yang melibatkan peran siswa secara aktif dalam kegiatan belajar mengajar, guna meningkatkan hasil belajar Matematika disetiap jenjang pendidikan. Salah satu model pembelajaran yang melibatkan peran siswa secara aktif adalah model pembelajaran kooperatif. Model pembelajaran kooperatif sangat cocok diterapkan pada pembelajaran matematika. Melalui model pembelajaran ini siswa dapat mengemukakan pemikirannya, saling bertukar pendapat, saling bekerja sama jika ada teman dalam kelompoknya yang mengalami kesulitan. Hal ini dapat meningkatkan motivasi siswa untuk mengkaji dan menguasai materi pelajaran matematika sehingga nantinya akan meningkatkan hasil belajar matematika siswa. Model pembelajaran kooperatif terdiri dan empat pendekatan yaitu: Student Teams Achievement Division (STAD), Jigsaw, IK (Investigasi Kelompok), dan pendekatan struktural. Pendekatan struktural terdiri dan dua tipe yaitu tipe Think Pair Share dan tipe NHT. Melihat penguasaan siswa terhadap materi matematika khususnya materi keliling dan luas bangun datar, maka dalam penelitian ini model pembelajaran yang dipilih adalah model pembelajaran kooperatif tipe Numbered Heads Together (NHT), karena pada model ini siswa menempati posisi sangat dominan dalam proses pembelajaran dan terjadinya kerjasama dalam kelompok dengan ciri utamanya adanya penomoran sehingga semua siswa berusaha untuk memahami setiap materi yang diajarkan dan bertanggungjawab atas nomor anggota masing-masing. Dengan pemilihan model ini, diharapkan pembelajaran yang terjadi dapat lebih bermakna dan membebani kesan yang kuat kepada siswa. 
Berdasarkan pemikiran di atas, maka peneliti melakukan suatu penelitian yang berjudul:"Penerapan Model Pembelajaran Kooperatif Tipe Numbered Heads Together (NHT) untuk Meningkatkan Hasil Belajar Siswa Materi Keliling dan Luas Bangun Datar Jajargenjang dan Segitiga Kelas IV SD Negeri 1 Lelewawo".

Masalah dalam penelitian ini adalah: Apakah hasil belajar siswa pada materi keliling dan luas bangun datar dapat ditingkatkan melalui model pembelajaran kooperatif tipe NHT di Kelas IV SD Negeri 1 Lelewawo? Tujuan penelitian ini adalah untuk meningkatkan hasil belajar siswa pada materi keliling dan luas bangun datar melalui penerapan pembelajaran kooperatif tipe NHT pada siswa kelas IV SD Negeri 1 Lelewawo. Penelitian ini diharapkan dapat memberikan manfaat bagi guru, siswa, sekolah dan penelitian lainnya.

\section{Metode}

Jenis penelitian adalah penelitian tindakan kelas (PTK. dilaksanakan di Kelas IV SD Negeri 1 Lelewawo Kolaka Utara semester ganjil tahun pelajaran 2016/2017 dengan subyek dalam penelitian ini adalah siswa kelas IV SD Negeri 1 Lelewawo Kabupaten Kolaka Utara yang mengikuti mata pelajaran matematika dengan materi pokok operasi hitung campuran bilangan bulat tahun ajaran 2016/2017 sebanyak 30. Penelitian tindakan kelas ini dilaksanakan dalam dua siklus yang terdiri dari empat tahapan yaitu perencanaan, pelaksanaan tindakan, observasi dan evaluasi serta refleksi Jenis data dalam penelitian ini adalah data kualitatif dan kuantitatif. Data kualitatif berupa kegiatan proses pembelajaran aktivitas belajar siswa dan aktivitas guru. Data kuantitatif berupa nilai hasil belajar siswa. Sumber data dalam penelitian ini adalah guru dan siswa Kelas IV SD Negeri 1 Lelewawo Data kualitatif akan dianalisis secara deskriptif kualitatif berdasarkan observasi, sedangkan data kuantitatif dianalisis secara kuantitatif menggunakan rumus:

$$
\begin{aligned}
& \% \text { Keterlaksanaan }=\frac{\text { Skorperolehan }}{\text { skorideal }} \times 100 \% \quad \text { (Nasution. 2003:29) } \\
& \text { Data hasil belajar siswa dianalisis dengan menggunakan rumus: } \\
& \text { Rata-rata }=\frac{\text { JawabanBenarjumlah nilai yang diperoleh siswa }}{\text { jumlah seluruh siswaTotalskor }} \times 100 \quad \text { (Rakh }
\end{aligned}
$$

Menentukan persentase ketuntasan belajar secara klasikal menggunakan rumus:

$$
\% \text { TuntasKlasikal }=\frac{\sum T B I}{N} x 100 \quad \text { (Nasution, 2008: 6.11) }
$$

Indikator keberhasilan dalam penelitian ini yaitu 1) Dari segi proses, tindakan dikatakan berhasil jika $80 \%$ skenario pembelajaran yang dibuat terlaksana dengan baik. 2) Dari segi hasil, tindakan dikatakan berhasil jika minimal $80 \%$ siswa telah memperoleh nilai minimal 65 (ketentuan KKM matematika untuk kelas IV SD Negeri 1 Lelewawo). 


\section{Hasil}

1. Hasil Belajar Siswa

Pada setiap akhir siklus dilakukan tes untuk mengukur hasil belajar siswa. Berikut ini adalah grafik hasil belajar siswa pada siklus 1 dan siklus 2:

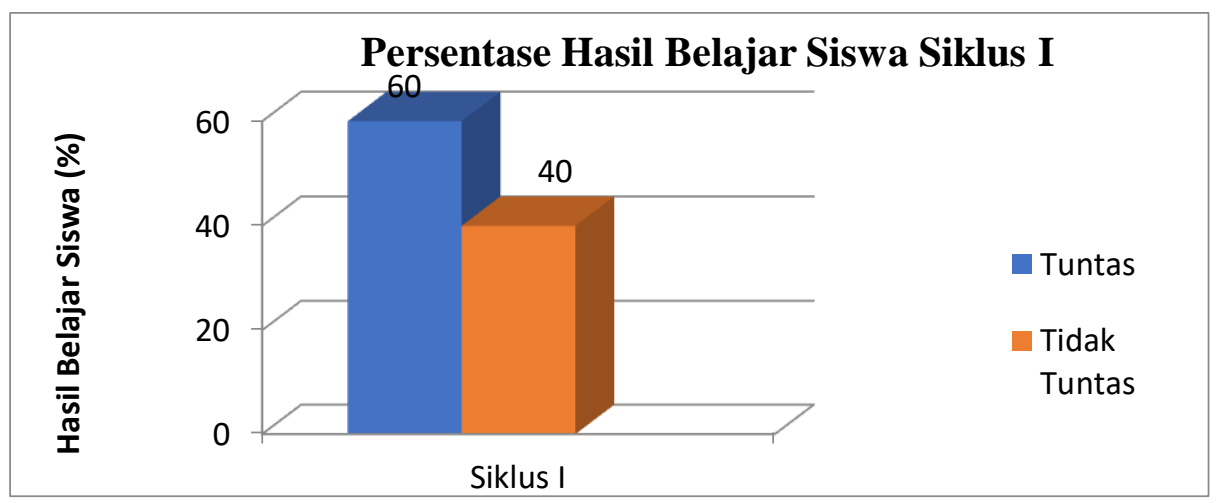

Gambar 1. Grafik Presentase Ketuntasan Hasil Belajar Siswa Siklus I

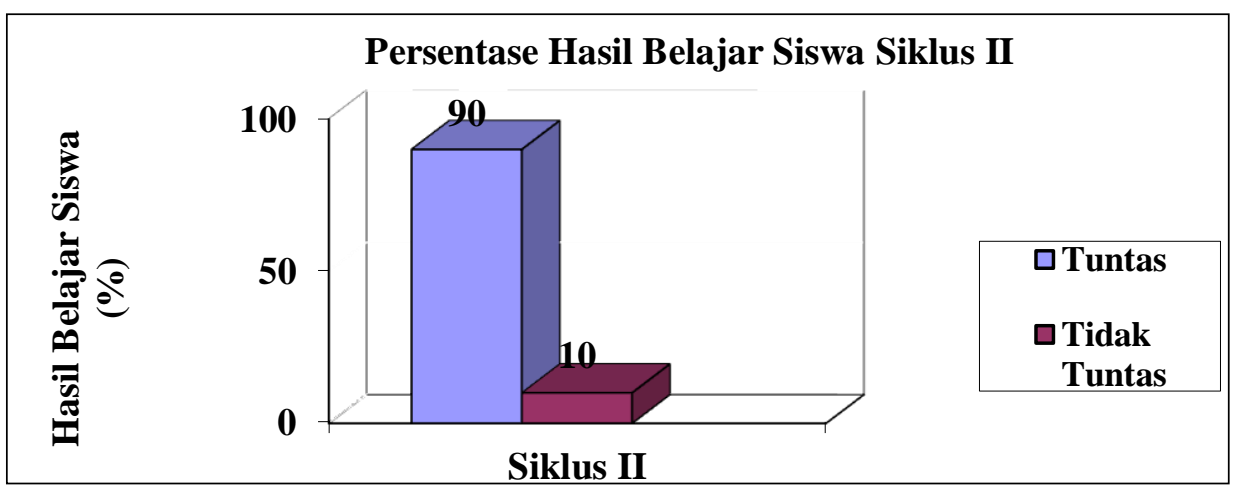

Gambar 2. Grafik Presentase Ketuntasan Hasil Belajar Siswa Siklus II

2. Aktivitas Guru dan Siswa

Pada saat pembelajaran berlangsung aktivitas guru dan siswa diamati oleh observer. Berikut ini adalah grafik aktivitas guru dan siswa pada siklus I dan II:

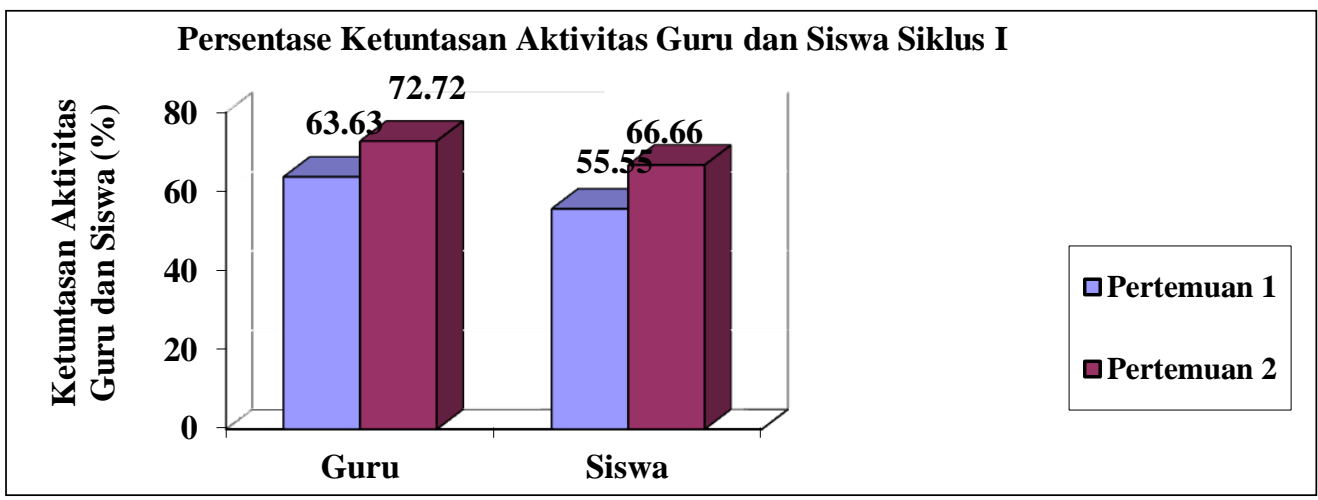

Gambar 3. Grafik Presentase Aktivitas Guru dan Siswa Siklus I 


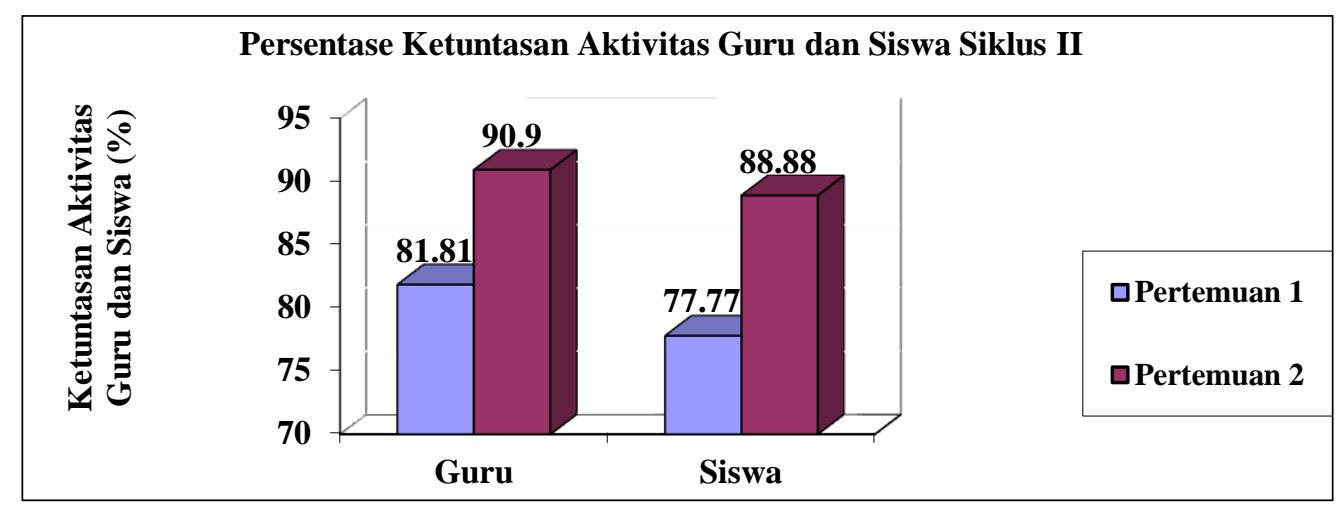

Gambar 4. Grafik Presentase Aktivitas Guru dan Siswa Siklus II

\section{Pembahasan}

Penelitian tindakan kelas (classroom action research)ini terdiri dari 2 siklus yang dilaksanakan sesuai dengan prosedur penelitian.Kuantitas pertemuan dalam setiap siklus didasarkan pada kepadatan materi yang dibahas.

Penelitian ini berakhir setelah pelaksanaan siklus II karena telah tercapai indikator kinerja yang telah ditetapkan.Pada siklus I, perolehan nilai siswa berdasarkan ketuntasan belajar hanya $60 \%$ siswa yang memperoleh nilai minimal 65 . Rendahnya nilai siswa pada siklus I disebabkan beberapa hal, antara lain karena siswa belum terbiasa mengikuti pembelajaran dengan model pembelajaran kooperatif tipe NHT. Selain itu juga disebabkan karena belum terlaksananya semua komponen dalam skenario pembelajaran.Berarti penelitian dilanjutkan pada siklus II karena belum memenuhi indikator kinerja yang telah ditetapkan.

Setelah siklus II, nilai siswa menunjukkan peningkatan menjadi 90\% siswa telah memperoleh nilai minimal 65 berarti telah mencapai indikator yang telah ditetapkan.

Proses pelaksanaan skenario pembelajaran oleh guru dan siswa siklus I ke siklus II juga mengalami peningkatan.Berdasarkan hasil observasiyang telah dilakukan oleh guru pada siklus I, menunjukkan guru belum dapat mengoorganisasikan waktu dengan baik. Hal ini dapat dilihat dari bertambahnya waktu yang diperlukan untuk membagi siswa dalam kelompok. Akibatnya kegiatan merangkum materi yang seharusnya dilakukan pada menit terakhir pertemuan gagal dilakukan.Terkadang pemantauan guru terhadap siswa dalam kelompok hanya terpaku pada kelompok tertentu saja. Sehingga saat ada kelompok lain yang membutuhkan bimbingan, guru tidak mampu melayani dengan baik. Sedangkan hasil observasi terhadap siswa pada siklus I menunjukkan siswa masih asing dengan model pembelajaran yang diterapkan, mengingat model pembelajaran ini merupakan hal yang masih baru bagi mereka. Hal ini terlihat dari sikap siswa yang masih kaku selama berada dalam kelompoknya.Masih banyak siswa yang tidak berdiskusi dengan teman kelompoknya, akibatnya banyak siswa yang kurang aktif dalam mengerjakan soal-soal dalam LKS.Hanya beberapa siswa yang dapat mempresentasikan hasil kerja kelompoknya dan banyak siswa yang merasa gugup ketika nomornya terpanggil untuk maju ke depan kelas. Persentase skenario pembelajaran oleh guru pada siklus I pertemuan pertama mencapai $63,63 \%$ dan pertemuan kedua meningkat menjadi $72,72 \%$ sedangkan oleh siswa pertemuan pertama mencapai 55,55\% dan pertemuan kedua meningkat menjadi 66,66\%. Hasil observasi yang telah dilakukan oleh guru dan siswa pada siklus II sudah sepenuhnya terlaksana. Persentase skenario pembelajaran oleh guru pada siklus II pertemuan pertama mencapai $81,81 \%$ dan pertemuan kedua meningkat menjadi $90,90 \%$ sedangkan oleh siswa pertemuan pertama mencapai $77,77 \%$ dan pertemuan kedua meningkat menjadi $88,88 \%$. Hasil tersebut sudah 
mencapai indikator kinerja untuk keberhasilan proses pelaksanaan skenario pembelajaran oleh guru dan siswa.

Berdasarkan hasil observasi dari kegiatan awal sampai dengan siklus II terjadi perubahan sikap pada siswa yaitu siswa menjadi lebih termotivasi untuk belajar.Hal ini terlihat, pada saat siswa kurang memperhatikan materi pelajaran yang diberikan oleh guru, dan setelah siklus II siswa lebih terfokus memperhatikan materi yang diberikan guru.

Dari uraian-uraian di atas dapat disimpulkan bahwa hasil belajar siswa kelas IV SD Negeri 5 Duruka pada materi bangun datar dapat ditingkatkan melalui model pembelajaran kooperatif tipe NHT.

Menurut Walgito (2004:169) mengungkapkan belajar merupakan sesuatu yang terjadi dalam diri individu yang disebabkan karena latihan dan pengalaman dan hal ini menimbulkan perubahan dalam perilaku. Belajar adalah merupakan suatu proses, suatu kegiatan dan bukan suatu hasil atau tujuan. Belajar bukan hanya mengingat, akan tetapi lebih luas daripada itu, yakni mengalami. Hasil belajar bukan suatu penguasaan hasil latihan, melainkan perubahan kelakuan (Hamalik, 2013:36).

Menurut Arikunto dalam Ekawarna (2011:41) hasil belajar adalah suatu hasil yang diperoleh siswa setelah mengikuti proses pengajaran yang dilakukan oleh guru. Hasil belajar ini biasanya dinyatakan dalam bentuk angka, huruf, atau kata-kata baik, sedang, kurang dan sebagainya.Hamalik dalam Ekawarna (2011:41) juga menjelaskan hasil belajar adalah perubahan tingkah laku pada diri siswa, yang dapat diamati dan diukur dalam bentuk perubahan pengetahuan, sikap dan keterampilan.Selanjutnya menurut Abdurrahman dalam Saminanto (2010:100) bahwa hasil belajar adalah kemampuan-kemampuan yang dimiliki siswa setelah ia menerima pengalaman belajar yang diperoleh melalui usaha dalam menyelesaikan tugas-tugas belajar.

Pembelajaran kooperatif merupakan sebuah kelompok strategi pengajaran yang melibatkan siswa bekerja secara berkolaborasi untuk mencapai tujuan bersama.Pembelajaran kooperatif disusun dalam sebuah usaha untuk meningkatkan partisipasi siswa, memfasilitasi siswa dengan pengalaman sikap kepemimpinan dan membuat keputusan dalam kelompok, serta memberikan kesempatan pada siswa untuk berinteraksi dan belajar bersama-sama siswa yang berbeda latar belakangnya.Jadi dalam pembelajaran kooperatif siswa berperan ganda yaitu sebagai siswa ataupun sebagai guru. Dengan bekerja secara kolaboratif untuk mencapai sebuah tujuan bersama, maka siswa akan mengembangkan keterampilan berhubungan dengan sesame manusia yang akan sangat bermanfaat bagi kehidupan di luar sekolah (Trianto, 2007:42).

Numbered Heads Together (NHT) atau penomoran berpikir bersama adalah merupakan jenis pembelajaran kooperatif yang dirancang untuk mempengaruhi pola interaksi siswa dan sebagai alternative terhadap struktur kelas tradisional.NHT pertama kali dikembangkan oleh Spenser Kagen (1993) untuk melibatkan lebih banyak siswa dalam menelaah materi yang tercakup dalam suatu pelajaran dan mengecek pemahaman mereka terhadap isi pelajaran tersebut (Trianto, 2007:62).

Menurut Slavin (2005:255-256) mengungkapkan tiap siswa dalam sebuah kelompok mempunyai nomor dan para siswa tersebut tahu bahwa hanya ada satu siswa yang akan dipanggil untuk mewakili kelompoknya. Suara dengungan yang semarak dari diskusi adalah usaha pada siswa untuk saling berbagi informasi supaya semua orang tahu jawabannya. Dengan cara itu mereka akan menerima sebuah poin tidak peduli nomor mana yang dipanggil. 


\section{Simpulan}

Berdasarkan hasil dan pembahasan penelitian yang dikemukakan, maka dapat disimpulkan bahwa hasil belajar siswa kelas IV SD Negeri 5 Duruka pada materi pokok bangun datar mengalami peningkatan melaluipenerapan model pembelajaran kooperatif tipe NHT. Hasil analisis data dapat dijelaskan satu-persatu berikut ini: Hasil observasi skenario pembelajaran aktivitas mengajar guru siklus I pertemuan 1 sebesar $63,63 \%$ dan pertemuan 2 sebesar $72,72 \%$, hasil observasi aktivitas belajar siswa siklus I pertemuan I sebesar 55,55\% dan pertemuan 2 sebesar 66,66\%. Hasil tes siswa untuk siklus I diperoleh sebesar $60 \%$ Tuntas dan $40 \%$ tidak tuntas. Kemudian hasil observasi skenario pembelajaran aktivitas mengajar guru siklus II pertemuan 1 sebesar 81,81\% dan pertemuan 2 sebesar 90,90\%, hasil observasi aktivitas belajar siswa siklus II pertemuan 1 sebesar 77,77\% dan pertemuan 2 sebesar 88,88\%. Hasil tes siswa untuk siklus II diperoleh sebesar 90\% Tuntas dan $10 \%$ tidak tuntas. Berdasarkan hasil observasi aktivitas mengajar guru dari siklus pertama ke siklus ke dua terjadi peningkatan sebesar $18,18 \%$. Hasiltes siswa siklus pertama ke siklus ke dua terjadi peningkatan sebesar $30 \%$ atau sebanyak 9 orang siswa.

\section{Referensi}

Ekawarna. 2011. Penelitian Tindakan Kelas. Jakarta: Gaung Persada.

Hamalik, Oemar. 2013. Kurikulum dan Pembelajaran. Jakarta:Bumi Aksara.

Nasution. 2003. Metode Penelitian Naturalistik Kualitatif. Bandung: Transito.

Nasution. 2008. Berbagai Pendekatan dalam Proses Belajar \& Mengajar. Cetakan keduabelas. Jakarta:Bumi Aksara.

Saminanto. 2010. Ayo Praktik PTK (Penelitian tindakan Kelas). Semarang: Rasail Media Group.

Slavin, E. R. 2005. Cooperative Learning Teori, Riset, dan Praktik. Bandung:Nusa Media.

Rakhmat, J. 2003. Metode Penelitian Komunikasi. Bandung: PT. Remaja Rosdakarya.

Trianto. 2007. Model-Model Pembelajaran Inovatif Berorientasi Konstruktivistik. Jakarta:Prestasi Pustaka.

Walgito, Bimo. 2004. Pengantar Psikologi Umum. Yogyakarta:Andi Offset 